\title{
A!
}

This is an electronic reprint of the original article.

This reprint may differ from the original in pagination and typographic detail.

Berdova, Maria; Ylivaara, Oili M. E.; Rontu, Ville; Törmä, Pekka T.; Puurunen, Riikka; Franssila, Sami

Fracture properties of atomic layer deposited aluminum oxide free-standing membranes

Published in:

JOURNAL OF VACUUM SCIENCE AND TECHNOLOGY A

DOI:

$10.1116 / 1.4893769$

Published: 01/01/2015

Document Version

Publisher's PDF, also known as Version of record

Please cite the original version:

Berdova, M., Ylivaara, O. M. E., Rontu, V., Törmä, P. T., Puurunen, R., \& Franssila, S. (2015). Fracture properties of atomic layer deposited aluminum oxide free-standing membranes. JOURNAL OF VACUUM SCIENCE AND TECHNOLOGY A, 33(1). https://doi.org/10.1116/1.4893769

This material is protected by copyright and other intellectual property rights, and duplication or sale of all or part of any of the repository collections is not permitted, except that material may be duplicated by you for your research use or educational purposes in electronic or print form. You must obtain permission for any other use. Electronic or print copies may not be offered, whether for sale or otherwise to anyone who is not an authorised user. 


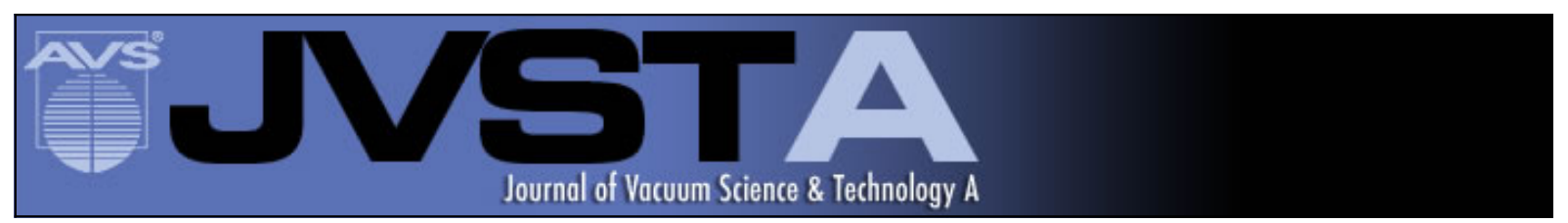

\section{Fracture properties of atomic layer deposited aluminum oxide free-standing membranes}

Maria Berdova, Oili M. E. Ylivaara, Ville Rontu, Pekka T. Törmä, Riikka L. Puurunen, and Sami Franssila

Citation: Journal of Vacuum Science \& Technology A 33, 01A106 (2015); doi: 10.1116/1.4893769

View online: http://dx.doi.org/10.1116/1.4893769

View Table of Contents: http://scitation.aip.org/content/avs/journal/jvsta/33/1?ver=pdfcov

Published by the AVS: Science \& Technology of Materials, Interfaces, and Processing

\section{Articles you may be interested in}

Deposition temperature dependence of material and Si surface passivation properties of O3-based atomic layer deposited Al2O3-based films and stacks

J. Vac. Sci. Technol. A 32, 01A128 (2014); 10.1116/1.4852855

Charge trapping analysis of $\mathrm{Al} 2 \mathrm{O} 3$ films deposited by atomic layer deposition using $\mathrm{H} 2 \mathrm{O}$ or $\mathrm{O} 3$ as oxidant J. Vac. Sci. Technol. B 31, 01A101 (2013); 10.1116/1.4766182

Trimethyl-aluminum and ozone interactions with graphite in atomic layer deposition of $\mathrm{Al} 2 \mathrm{O} 3$

J. Appl. Phys. 112, 104110 (2012); 10.1063/1.4766408

Controlling the fixed charge and passivation properties of $\mathrm{Si}(100) / \mathrm{Al} 2 \mathrm{O} 3$ interfaces using ultrathin $\mathrm{SiO} 2$ interlayers synthesized by atomic layer deposition

J. Appl. Phys. 110, 093715 (2011); 10.1063/1.3658246

Critical tensile and compressive strains for cracking of $\mathrm{Al} 2 \mathrm{O} 3$ films grown by atomic layer deposition

J. Appl. Phys. 109, 084305 (2011); 10.1063/1.3567912

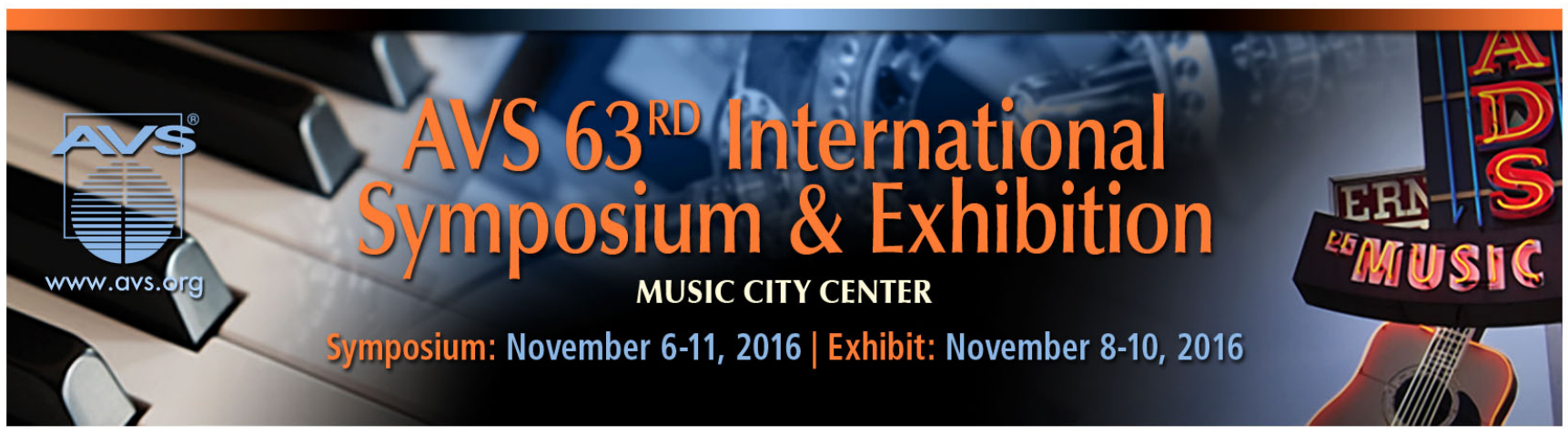




\title{
Fracture properties of atomic layer deposited aluminum oxide free-standing membranes
}

\author{
Maria Berdova ${ }^{\text {a) }}$ \\ Department of Materials Science and Engineering, Aalto University, P.O. Box 16200, FI-00076 Aalto, \\ Finland \\ Oili M. E. Ylivaara \\ VTT Technical Research Centre of Finland, P.O. Box 1000, FI-02044VTT, Finland \\ Ville Rontu \\ Department of Materials Science and Engineering, Aalto University, P.O. Box 16200, FI-00076 Aalto, \\ Finland \\ Pekka T. Törmä \\ Department of Micro- and Nanosciences, Aalto University, P.O. Box 13500, 00076 Aalto, Finland \\ Riikka L. Puurunen \\ VTT Technical Research Centre of Finland, P.O. Box 1000, FI-02044VTT, Finland

\begin{abstract}
Sami Franssila
Department of Materials Science and Engineering, Aalto University, P.O. Box 16200, FI-00076 Aalto,
\end{abstract} \\ Finland
}

(Received 28 May 2014; accepted 11 August 2014; published 25 August 2014)

\begin{abstract}
The fracture strength of $\mathrm{Al}_{2} \mathrm{O}_{3}$ membranes deposited by atomic layer deposition at 110, 150, 200, and $300{ }^{\circ} \mathrm{C}$ was investigated. The fracture strength was found to be in the range of $2.25-3.00 \mathrm{GPa}$ using Weibull statistics and nearly constant as a function of deposition temperature. This strength is superior to common microelectromechanical systems materials such as diamondlike carbon, $\mathrm{SiO}_{2}$, or $\mathrm{SiC}$. As-deposited membranes sustained high cycling pressure loads $>10$ bar/s without fracture. Films featured, however, significant reduction in the resistance to failure after annealing $\left(800^{\circ} \mathrm{C}\right)$ or high humidity $\left(95 \%, 60^{\circ} \mathrm{C}\right)$ treatments. (C) 2014 American Vacuum Society.

[http://dx.doi.org/10.1116/1.4893769]
\end{abstract}

\section{INTRODUCTION}

Thin films produced by atomic layer deposition (ALD) have attracted great attention. Due to their excellent properties, ALD films have very good conformality and uniformity, and they can be deposited on various three dimensional substrates. ALD films have been applied in biomedical, optical, electronic devices, etc. ${ }^{1}$ ALD films are widely used in microand nanoelectromechanical systems (MEMS/NEMS): for instance, as antistiction, wear resistant, or other functional layers. $^{2-10}$ MEMS/NEMS consist of moving parts with mechanical functions, where fracture strength (resistance to failure) and durability are important parameters. Moreover, moisture and temperatures can influence to the fracture strength, and therefore, this influence must be analyzed and understood prior to device fabrication. Failure characterization of nanometer-thick films is challenging: besides complex sample preparation steps, analysis may require an additional modeling. Bulge technique is a straightforward and simple mechanical test, which produces fracture strength values for thin films. ${ }^{1-15}$ Fracture toughness testing is more demanding and requires patterning of initial crack with nanometer size and shape control (by, e.g., focused ion beam). ${ }^{15}$

In this paper, the fracture bulge technique with freestanding $\mathrm{ALD} \mathrm{Al}_{2} \mathrm{O}_{3}$ membranes deposited at 110, 150, 200,

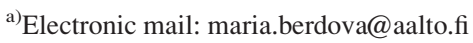

and $300{ }^{\circ} \mathrm{C}\left(70-75 \mathrm{~nm}\right.$ thick) was conducted. ALD $\mathrm{Al}_{2} \mathrm{O}_{3}$ films with excellent mechanical stability and high robustness are demonstrated. In addition to the experiments on effect of humidity and annealing on strength, we carried out high speed pressure cycling tests on membranes. These conditions were selected as ones which could be during MEMS/NEMS sensors operations, for example, in space or automotive applications. ${ }^{16,17}$ These sensors should reliably operate during outgassing of moisture or temperature drifts without device disruption. ${ }^{18}$ Another example of MEMS is microheaters and microhotplates, which operate at significantly high temperatures (up to $1000^{\circ} \mathrm{C}$ ). ${ }^{19,20}$ It is therefore important to evaluate the change in fracture strength of thin films after heating or moisture treatments.

\section{EXPERIMENT}

ALD $\mathrm{Al}_{2} \mathrm{O}_{3}$ films were deposited in a top-flow Picosun ${ }^{\mathrm{TM}}$ R-150 ALD reactor. Precursors were trimethylaluminum (electronic grade $\mathrm{Me}_{3} \mathrm{Al}$, SAFC Hitech) and deionized water. $\mathrm{Me}_{3} \mathrm{Al}$ precursor was cooled with a Peltier element to about $17^{\circ} \mathrm{C}$ and water was used at a room temperature without cooling. ${ }^{21}$ Nitrogen (purity $>99.999 \%$ ) was used both as a purge gas and for flushing the reactant lines with a constant $200 \mathrm{sccm}$ flow. Precursor dose and purge times were 0.1 and $4.0 \mathrm{~s}$, respectively, for films deposited at $110^{\circ} \mathrm{C}$ to $200^{\circ} \mathrm{C}$ and 0.1 and $1.0 \mathrm{~s}$ for film deposited at $300^{\circ} \mathrm{C}$. The number of ALD cycles was 962, 853, 778, and 756 for 110,150 , 
200 , and $300^{\circ} \mathrm{C}$, respectively. Film thicknesses were measured with SCI FilmTek $2000 \mathrm{M}$ spectroscopic reflectometer using 25-point automated measurement. Dispersion of the refractive index for the $\mathrm{Al}_{2} \mathrm{O}_{3}$ deposited at $300{ }^{\circ} \mathrm{C}(5000$ cycles) was used as a standard model for the measurement recipe. The targeted film thickness was $75 \mathrm{~nm}$, and the measured film thickness was in the range of $73 \pm 2 \mathrm{~nm}$.

After the deposition of the ALD films on double side polished silicon substrate [Fig. 1(a)], the back side was patterned employing laser lithography (Microtech LW405) and wet etching of $\mathrm{Al}_{2} \mathrm{O}_{3}$ in buffered hydrofluoric acid (BHF) for $1 \mathrm{~min}$ at $31{ }^{\circ} \mathrm{C}$ [Fig. 1(b)], while the top side $\mathrm{Al}_{2} \mathrm{O}_{3}$ was protected by standard photoresist to avoid etching of test structures. The patterned $\mathrm{Al}_{2} \mathrm{O}_{3}$ from the back side acted as an etch mask for deep reactive ion etching (DRIE) since the etch selectivity of silicon to $\mathrm{Al}_{2} \mathrm{O}_{3}$ is 66 $000: 1,{ }^{22}$ and $\mathrm{Al}_{2} \mathrm{O}_{3}$ from the top side acted as an etch stop layer. Finally, membranes ( $400 \mu \mathrm{m}$ in radius) were released by DRIE Bosch process [Fig. 1(b)] utilizing $\mathrm{SF}_{6}, \mathrm{O}_{2}$ and $\mathrm{C}_{4} \mathrm{~F}_{8}$ gases (STS Advanced Silicon Etch). Additionally, each chip $\left(7 \mathrm{~mm}^{2}\right)$ with a test structure was defined by patterning line borders to avoid dicing [Fig. 1(c)]. The fabrication of free-standing membranes was reported in detail elsewhere. $^{14}$

After sample fabrication, some membranes underwent annealing (PEO-601) at $800{ }^{\circ} \mathrm{C}$ for $15 \mathrm{~min}$ in nitrogen ambient, while others were kept in an environmental chamber with constant relative humidity (RH) of $95 \%$ at $60{ }^{\circ} \mathrm{C}$ for 18 $\mathrm{h}$ (around 15 samples per each deposition temperature for every treatment).

Due to the fact that crystalline $\mathrm{Al}_{2} \mathrm{O}_{3}$ has different elastic properties from amorphous films, ${ }^{23}$ and crystallization can start at annealing temperatures about $750-800{ }^{\circ} \mathrm{C},{ }^{24}$ annealed $\mathrm{Al}_{2} \mathrm{O}_{3}$ films were analyzed for crystallinity using grazingincidence X-ray diffraction (GIXRD) method.

In the bulge testing, thin film breakage was brought about by applying overpressure to membrane from the top side [Fig. 1(d)]. The differential pressure (compressed air) was gradually increased by $100 \mathrm{mbar} / \mathrm{s}$ until membrane rupture. Maximum available differential pressure was 3500 mbar. The breakage pressure was recorded by measurement software. In addition, as-deposited membranes were subjected for high speed pressure cycling testing: ten cycles with the maximum available ramp rate of $\gg 10 \mathrm{bar} / \mathrm{s}$ were applied until 1500 mbar. Next ten cycles with the same ramp rate were applied to the same membrane until 2000 mbar.

The fracture strength $\sigma_{\text {fracture }}$ of a membrane was evaluated from maximum pressure $P_{\max }$ using equation ${ }^{12-14}$

$$
\sigma_{\text {fracture }}^{3}=\frac{1}{24} \frac{E P_{\max }^{2} a^{2}}{(1-\nu) h^{2}},
$$

where $a$ is the membrane radius, $h$ is the film thickness, $E$ is the Young's modulus, and $v$ is the Poisson's ratio [assumed to be 0.24 (Ref. 25) here] of $\mathrm{Al}_{2} \mathrm{O}_{3}$ film.

The probability of failure $P_{f}$ was estimated by the probabilistic Weibull distribution, ${ }^{26-30}$ where the failure probability for a specimen with a surface area $A$ under uniformly applied stress $\sigma$ is described by function

$$
P_{f}=1-\exp \left[-A\left(\frac{\sigma}{\sigma_{c}}\right)^{m}\right],
$$

where $\sigma_{c}$ is the characteristic failure strength (scale parameter) value of a unit area of material at $63 \%$ or $\left(1-e^{-1}\right) \cdot 100 \%, m$ is the Weibull modulus (shape parameter), which evaluates the scatter of the strength data and measures engineering reliability.

The expected mean fracture strength was calculated from $^{30,31}$

$$
\bar{\sigma}=\frac{\sigma_{c}}{A^{1 / m}} \cdot \Gamma\left(1+\frac{1}{m}\right),
$$

and the standard deviation from

$$
s=\sqrt{\bar{\sigma}^{2} \cdot\left(\frac{\Gamma\left(1+\frac{2}{m}\right)}{\Gamma^{2}\left(1+\frac{1}{m}\right)}\right)},
$$

where $\Gamma(z)$ is the gamma function. (a)

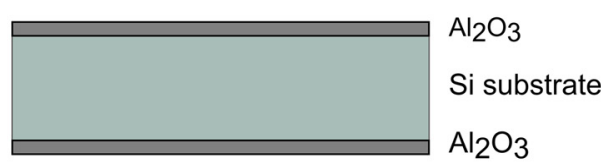

(b)

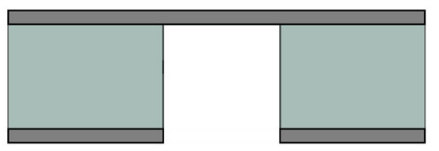

(c)

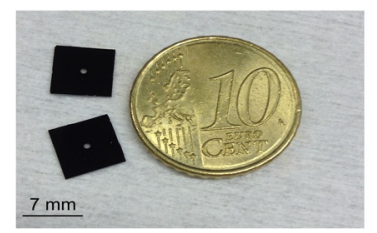

(d)

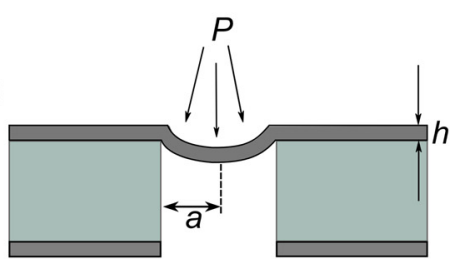

FIG. 1. (Color online) Fabrication process of free-standing membranes and schematic image of the fracture bulge test principle: (a) atomic layer deposition of $\mathrm{Al}_{2} \mathrm{O}_{3}$ from both sides; (b) wet etching of $\mathrm{Al}_{2} \mathrm{O}_{3}$ in $\mathrm{BHF}$ from the back side, membrane release using dry etching; (c) photo image of test structures; (d) overpressure $P$ (compressed air) is applied from the membrane top, where $a$ is the radius, $h$ is thickness of membrane. 


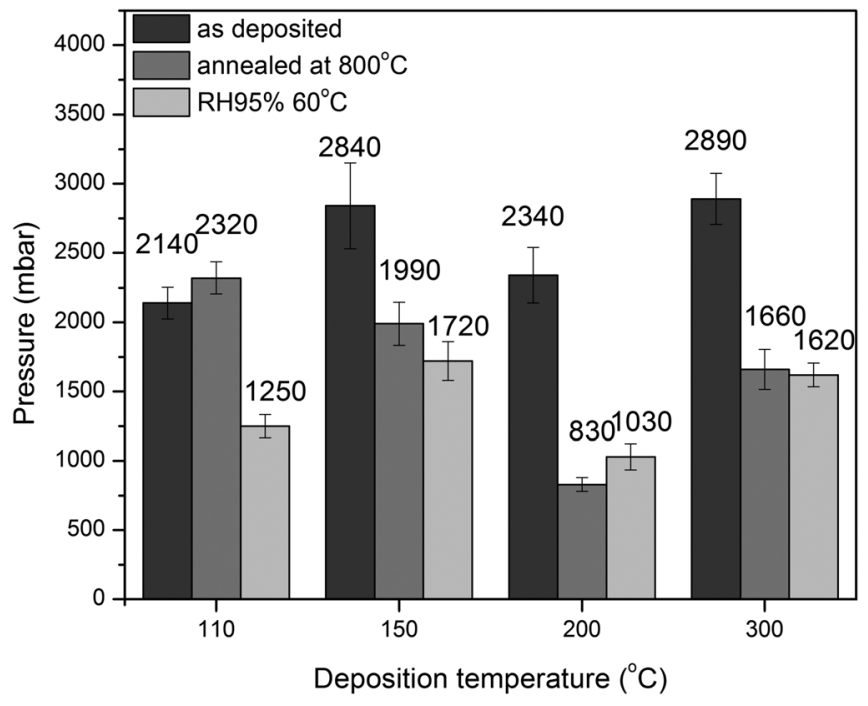

FIG. 2. Average breakage pressure values vs deposition temperatures.

\section{RESULTS AND DISCUSSION}

The bulge technique was used to evaluate the fracture strength of $\mathrm{ALD} \mathrm{Al}_{2} \mathrm{O}_{3}$ deposited at four different temperatures. Overpressure with maximum value of 3500 mbar was applied to the suspended membrane until fracture took place. The measured breakage pressure values are shown in Fig. 2. As can be seen, films deposited at $150{ }^{\circ} \mathrm{C}$ and $300^{\circ} \mathrm{C}$ tolerated higher pressures than those deposited at $110^{\circ} \mathrm{C}$ or $200^{\circ} \mathrm{C}$. All membranes survived after high speed pressure cycling without any failure. This is a considerable merit since membranes could withstand shock pressure impacts with a high robustness needed for various MEMS devices. However, after annealing or high humidity treatments, membranes became significantly weaker (with exception of the sample deposited at $110^{\circ} \mathrm{C}$ ).

The fracture strength was determined by Eq. (1). GIXRD revealed no significant peaks indicating amorphous nature of all annealed $\mathrm{Al}_{2} \mathrm{O}_{3}$ films. Therefore, Young's moduli were assumed to be $150 \mathrm{GPa}$ for deposition at $110^{\circ} \mathrm{C}$, and $170 \mathrm{GPa}$ for all other deposition temperatures. ${ }^{21}$

Table I represents shape and scale parameters derived from failure probability-fracture strength fits (Fig. 3) using probabilistic Weibull distribution [Eq. (2)]. The Weibull modulus of each test structure was defined from the slope of the fit, and the characteristic strength was estimated with probability of $63 \%$. As most good engineering ceramics,

TABLE I. Scale $\left(\sigma_{c}\right)$ and shape $(m)$ parameters for all test structures.

\begin{tabular}{lccc}
\hline $\begin{array}{l}\text { Deposition } \\
\mathrm{T}\left({ }^{\circ} \mathrm{C}\right)\end{array}$ & $\begin{array}{c}\text { As-deposited } \\
\text { scale }(\mathrm{GPa})^{m}\end{array}$ & $\begin{array}{c}\text { After annealing } \\
\text { scale }(\mathrm{GPa})^{m}\end{array}$ & $\begin{array}{c}\text { After humidity } \\
\text { scale }(\mathrm{GPa})^{m}\end{array}$ \\
\hline 110 & $2.32^{16.8}$ & $2.41^{19.2}$ & $1.62^{13.6}$ \\
150 & $3.07^{9.0}$ & $2.36^{14.0}$ & $2.15^{11.1}$ \\
200 & $2.62^{9.8}$ & $1.30^{14.7}$ & $1.51^{8.5}$ \\
300 & $3.10^{15.4}$ & $2.16^{11.7}$ & $2.10^{14.7}$ \\
\hline \hline
\end{tabular}

${ }^{\mathrm{a}} 25-30 \%$ of test structures failed after annealing without any mechanical load.

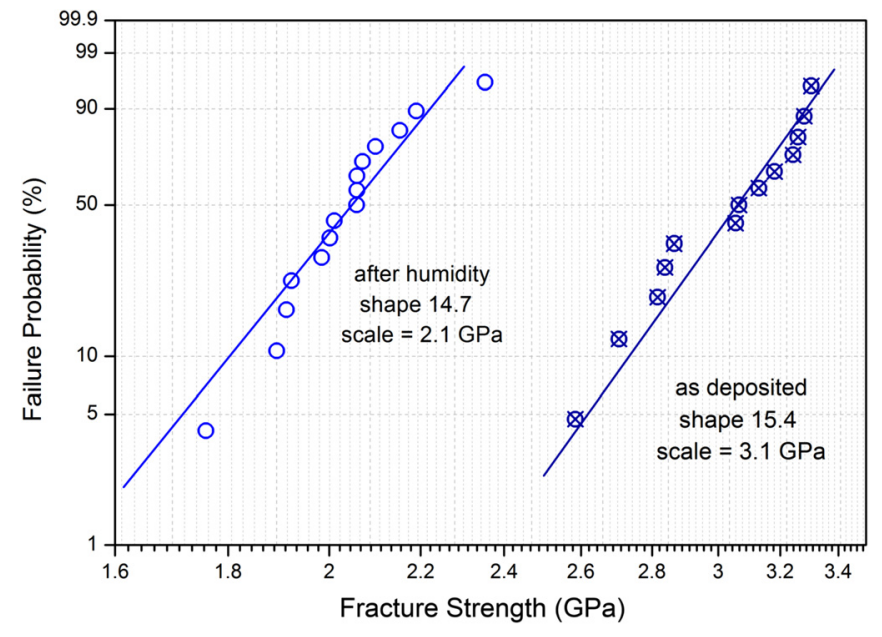

FIG. 3. (Color online) Weibull diagrams: failure probability vs fracture strength, where characteristic failure strength is scale and Weibull modulus is shape parameter. Shown for $\mathrm{Al}_{2} \mathrm{O}_{3}$ deposited at $300^{\circ} \mathrm{C}$.

$\mathrm{Al}_{2} \mathrm{O}_{3}$ had the shape parameter about ten and higher. Aluminum oxide films deposited at $150{ }^{\circ} \mathrm{C}$ and $300^{\circ} \mathrm{C}$ had the highest values of the scale parameter. However, the scale parameter of these films was reduced by $\sim 30 \%$ after annealing or moisture treatments. Interestingly, thin films deposited at $200^{\circ} \mathrm{C}$ reduced their scale parameter almost by a factor of two after high humidity or annealing.

Figure 4 shows the dependence of the mean fracture strength values [Eq. (3)] versus deposition temperature for all sample types: as-deposited, annealed, and treated in high humidity chamber. As observed, the fracture strength degraded significantly after being annealed or exposed to the high humidity. Error sources include minor membrane thickness variation due to ALD, the Bosch etch process undercut affects membrane size and thickness to some extent.

The fracture strength of as-deposited films is wellcorrelated with the earlier work where the strength $\mathrm{Al}_{2} \mathrm{O}_{3}$

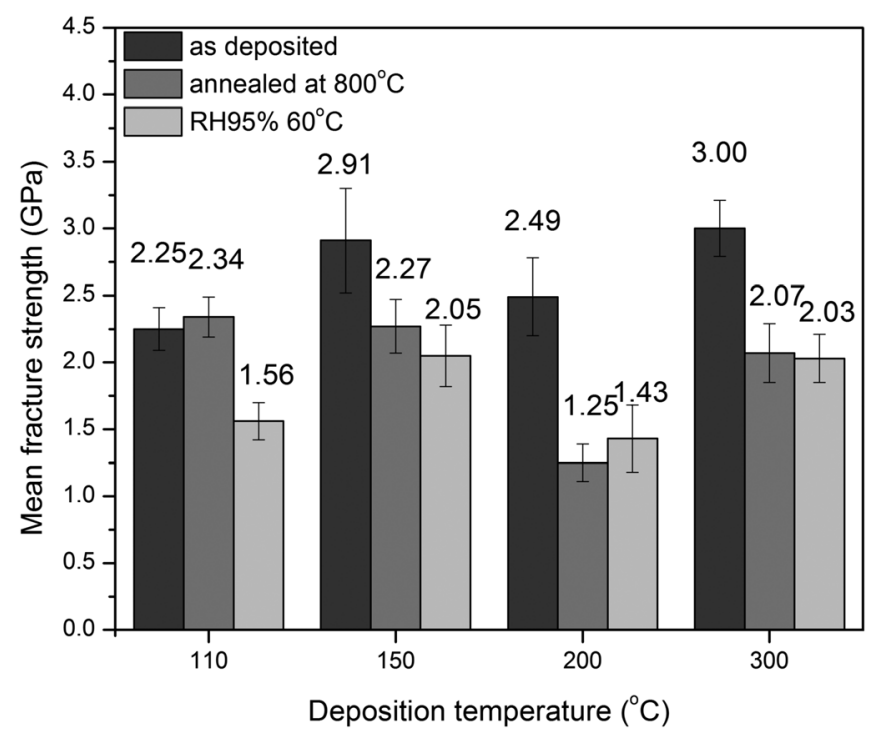

FIG. 4. Mean fracture strength values [Eq. (3)] vs deposition temperatures. 
films was of $2.56 \pm 0.21 \mathrm{GPa}$ (deposited at $220{ }^{\circ} \mathrm{C}$ ). ${ }^{14}$ Asdeposited $\mathrm{Al}_{2} \mathrm{O}_{3}$ exhibits significantly high fracture strength values in comparison with common MEMS materials such as silicon oxide, diamondlike carbon (DLC) or silicon carbide: 0.6-1.9 GPa (Ref. 32) for silicon oxide, 0.7 GPa (Ref. 33) for DLC, and 0.81 GPa (Ref. 34) for silicon carbide. The fracture strength of aluminum oxide is comparable with polysilicon films, whose strength is about $3 \mathrm{GPa}$ (Ref. 34) and slightly lower than ultrananocrystalline diamond or silicon nitride deposited by low pressure chemical vapor deposition: fracture strengths are 3.95-5.03 GPa (Ref. 33) and 5.69 GPa (Ref. 11), respectively.

High humidity reduced the $\mathrm{Al}_{2} \mathrm{O}_{3}$ membrane fracture strength. ALD aluminum oxide has been studied extensively as a water vapor barrier, and its tendency to degrade is well documented. ${ }^{35-37}$ One of very few reports on mechanical properties of alumina films is from $1969,{ }^{38}$ when it was reported that Young's modulus of $\mathrm{Al}_{2} \mathrm{O}_{3}$ films is reduced as a function of absolute humidity. It has also been shown that it is difficult to measure inherent strength of alumina because even low humidity in the range of $10-40 \% \mathrm{RH}$ is affecting the results. ${ }^{39}$ They proposed sample coating and nitrogen enclosure for the measurements. Others have shown that even very thin coatings, a few nanometer $\mathrm{TiO}_{2}$ or $\mathrm{NiO}$, can remarkably stabilize alumina under water immersion. ${ }^{40} \mathrm{ALD}$ $\mathrm{Al}_{2} \mathrm{O}_{3}$ is etched by deionized water with the etch rate of $0.2 \mathrm{~nm} / \mathrm{min} .{ }^{41}$ Water is able to penetrate the lattice of the $\mathrm{Al}_{2} \mathrm{O}_{3}$ film, and possibly react with hydroxyl groups, creating paths for moisture penetration. ${ }^{39}$ Thus, corrosion and dissolution of the film in water could be the reasons for the strength reduction.

In case of annealing (except for sample deposited at $110^{\circ} \mathrm{C}$ ), the decrease in resistance to failure can be explained by modification in composition (outgassing) after annealing. ${ }^{42,43}$ It has been reported that hydrogen and oxygen contents are reduced during annealing. ${ }^{42,43}$ Moreover, annealing induces changes in stress level that can lead to failure. Indeed, some of our membranes failed after annealing without any mechanical load (25-30\% of samples).

The fracture strength of bulk $\mathrm{Al}_{2} \mathrm{O}_{3}$ is known to decrease with increasing temperature and relative humidity. ${ }^{39,44}$ The same tendency was observed in our results: high humidity and annealing had a deleterious effect to the strength of $\mathrm{ALD} \mathrm{Al}_{2} \mathrm{O}_{3}$, degrading the membrane pressure tolerance and therefore weakening the material strength.

\section{CONCLUSIONS}

Reliable MEMS performance significantly depends on materials used for its fabrication. $\mathrm{ALD} \mathrm{Al}_{2} \mathrm{O}_{3}$ can be considered as a successful candidate for fabricating reliable freestanding structures. As-deposited $\mathrm{ALD} \mathrm{Al}_{2} \mathrm{O}_{3}$ membranes exhibited high mechanical robustness and considerable fracture strength of 2.25-3.00 GPa. Aluminum oxide films deposited at $150{ }^{\circ} \mathrm{C}$ and $300{ }^{\circ} \mathrm{C}$ tolerated higher pressures; however, the mean fracture strength remained nearly constant as a function of deposition temperature. Furthermore, as-deposited membranes sustained high speed pressure cycling without breakage. High humidity and annealing at high temperatures were found to reduce fracture strength clearly. Future work is required to evaluate the size effect of ALD thin films and to elucidate the mechanism of humidity induced failure.

\section{ACKNOWLEDGMENTS}

The authors acknowledge the provision of facilities and technical support by Micronova Nanofabrication Center of Aalto University. The work was undertaken within MECHALD project from TEKES (Finnish Funding Agency for Innovation) and is linked to the Finnish Center of Excellence on Atomic Layer Deposition (funded by Academy of Finland). M.B. is funded by Aalto School of Chemical Technology Ph.D. student grant and by The Finnish National Graduate School in Nanoscience (NGS Nano). The authors are thankful to Tuomas Pärnänen for the help with high humidity treatments and to Saima Ali for the GIXRD measurements.

${ }^{1}$ E. Marin, A. Lanzutti, F. Andreatta, M. Lekka, L. Guzman, and L. Fedrizzi, Corros. Rev. 29, 191 (2011).

${ }^{2}$ T. W. Scharf, S. V. Prasad, M. T. Dugger, P. G. Kotula, R. S. Goeke, and R. K. Grubbs, Acta Mater. 54, 4731 (2006).

${ }^{3}$ R. L. Puurunen, H. Kattelus, and T. Suntola, in Atomic Layer Deposition in MEMS Technology, edited by V. Lindroos, M. Tilli, A. Lehto, and T. Motooka (Elsevier, Boston, Oxford, 2010), pp. 433-446.

${ }^{4}$ R. L. Puurunen, J. Saarilahti, and H. Kattelus, ECS Trans. 11, 3 (2007).

${ }^{5}$ R. L. Puurunen et al. Sens. Actuators A 188, 240 (2012).

${ }^{6}$ T. M. Mayer, J. W. Elam, S. M. George, P. G. Kotula, and R. S. Goeke, Appl. Phys. Lett. 82, 2883 (2003).

${ }^{7}$ M. Ritala and J. Niinistö, ECS Trans. 25, 641 (2009).

${ }^{8}$ K. Gall, M. Hulse, M. L. Dunn, D. Finch, S. M. George, and B. A. Corff, J. Mater. Res. 18, 1575 (2003).

${ }^{9}$ N. D. Hoivik, J. W. Elam, R. J. Linderman, V. M. Bright, S. M. George, and Y. C. Lee, Sens. Actuators A 103, 100 (2003).

${ }^{10}$ C. F. Herrmann, F. W. DelRio, V. M. Bright, and S. M. George, J. Micromech. Microeng. 15, 984 (2005).

${ }^{11}$ R. L. Edwards, G. Coles, and W. N. Sharpe, Jr., Exp. Mech. 44, 49 (2004).

${ }^{12}$ Y. Pickhardt and D. L. Smith, J. Vac. Sci. Technol. 14, 823 (1977).

${ }^{13}$ Z. Xianghui, A. Beyer, and A. Gölzhäuser, Beilstein J. Nanotechnol. 2, 826 (2011).

${ }^{14} \mathrm{M}$. Berdova et al. Acta Mater. 66, 370 (2014).

${ }^{15}$ B. Merle and M. Göken, Acta Mater. 59, 1772 (2011).

${ }^{16}$ H. R. Shea, MOEMS-MEMS 2006 Micro and Nanofabrication, International Society for Optics and Photonics, 2006.

${ }^{17}$ C. Acars, A. R. Schofield, A. A. Trusov, L. E. Costlow, and A. M. Shkel, Sens. J. 9, 1895 (2009).

${ }^{18}$ R. Osiander, M. A. G. Darrin, and J. L. Champion, MEMS and Microstructures in Aerospace Applications (CRC Press, Boca Raton, FL, 2005).

${ }^{19}$ J. Lee and W. P. King, Sens. Actuators A 136, 291 (2007).

${ }^{20}$ J. Lee, T. L. Wright, M. R. Abel, E. O. Sunden, A. Marchenkov, S. Graham, and W. P. King, J. Appl. Phys. 101, 014906 (2007).

${ }^{21}$ O. M. E. Ylivaara et al. Thin Solid Films 552,124 (2014).

${ }^{22}$ L. Sainiemi and S. Franssila, J. Vac. Sci. Technol. B 25, 801 (2007).

${ }^{23}$ B. Holm, R. Ahuja, Y. Yourdshahyan, B. Johansson, and B. I. Lundqvist, Phys. Rev. B 59, 12777 (1999).

${ }^{24}$ V. Miikkulainen, M. Leskelä, M. Ritala, and R. L. Puurunen, J. Appl. Phys. 113, 021301 (2013).

${ }^{25}$ D. C. Miller, R. R. Foster, S. H. Jen, J. A. Bertrand, S. J. Cunningham, A. S. Morris, Y. C. Lee, S. M. George, and M. L. Dunn, Sens. Actuators A 164, 58 (2010).

${ }^{26}$ C. Lu, R. Danzer, and F. D. Fischer, Phys. Rev. E 65, 067102 (2002).

${ }^{27}$ R. Danzer, P. Supancic, J. Pascual, and T. Lube, Eng. Fract. Mech. 74, 2919 (2007). 
${ }^{28}$ O. M. Jadaan, N. N. Nemeth, J. Bagdahn, and W. N. Sharpe, Jr., J. Mater. Sci. 38, 4087 (2003).

${ }^{29}$ F. Ericson and J. Å. Schweitz, J. Appl. Phys. 68, 5840 (1990).

${ }^{30}$ S. Greek, F. Ericson, S. Johansson, M. Fürtsch, and A. Rump, J. Micromech. Microeng. 9, 245 (1999).

${ }^{31}$ K. Hergen, R. Aigner, and J. Binder, Trans. Electron. Dev. 47, 1522 (2000).

${ }^{32}$ T. Tsuchiya, A. Inoue, and J. Sakata, Sens. Actuators A 82, 286 (2000).

${ }^{33}$ H. D. Espinosa, B. C. Prorok, B. Peng, K. H. Kim, N. Moldovan, O. Auciello, J. A. Carlisle, D. M. Gruen, and D. C. Mancini, Exp. Mech. 43, 256 (2003).

${ }^{34}$ W. N. Sharpe, Jr., J. Bagdahn, K. Jackson, and G. Coles, J. Mater. Sci. 38, 4075 (2003).

${ }^{35}$ J. Meyer, H. Schmidt, W. Kowalsky, T. Riedl, and A. Kahn, Appl. Phys. Lett. 96, 243308 (2010).

${ }^{36}$ A. A. Dameron, S. D. Davidson, B. B. Burton, P. F. Carcia, R. S. McLean, and S. M. George, J. Phys. Chem. C 112, 4573 (2008).
${ }^{37}$ P. F. Carcia, R. S. McLean, and M. H. Reilly, Appl. Phys. Lett. 97, 221901 (2010).

${ }^{38}$ J. C. Grosskreutz, J. Electrochem. Soc. 116, 1232 (1969).

${ }^{39}$ S. J. Cho, K. J. Yoon, Y. C. Lee, and M. C. Chu, Mater. Lett. 57, 2751(2003).

${ }^{40}$ A. Bulusu, H. Kim, D. Samet, and S. Graham, Jr., J. Phys. D: Appl. Phys. 46, 084014 (2013).

${ }^{41}$ R. L. Puurunen, J. Kiihamäki, and H. Kattelus, "Controlling the solubility of ALD aluminium oxide in deionised water," AVS Topical Conference on Atomic Layer Deposition (2005).

${ }^{42}$ B. Vermang, H. Goverde, V. Simons, I. De Wolf, J. Meersschaut, S. Tanaka, J. John, J. Poortmans, and R. Mertens, "A study of blister formation in $\mathrm{ALD} \mathrm{Al}_{2} \mathrm{O}_{3}$ grown on silicon," Photovoltaic Specialists Conference (2012).

${ }^{43}$ L. Zhang, H. C. Jiang, C. Liu, J. W. Dong, and P. Chow, J. Phys. D: Appl. Phys. 40, 3707 (2007).

${ }^{44}$ J. J. Kruzic, R. M. Cannon, and R. O. Ritchie. J. Am. Ceram. Soc. 88, 2236 (2005). 